\title{
LEGALIZACJA SAMOWOLI BUDOWLANYCH W POLSKIM SYSTEMIE PRAWNYM
}

\section{Abstract \\ Legalisation of unlawful building work in the Polish legal system}

This paper presents a legal regulation regarding the institution of unlawful building work legalisation in Poland combining its historical review and evaluation. The paper shows the complexity of the problem and the difficulty of providing a legal regulation of the matter. The updated regulations on the procedure of unlawful building work legalisation came into force in Poland on 19 September 2020. After changing the legal regulations, the final decision on the legalisation of unlawful building work still remains in the hands of construction supervision authorities. However, in contrast to the previous legal status, a legalisation procedure can be initiated only upon developer's request. In addition, the lawmaker has introduced an option to legalise unlawful building work completed over 20 years ago in a simplified legalisation procedure. The final part of the paper presents all procedures for unlawful building work legalisation effective from 19 September 2020 as well as general conclusions regarding the institution under scrutiny.

Keywords: administrative proceedings, building law, unlawful building work, unlawful building work legalisation

\section{Streszczenie}

Niniejszy artykuł przedstawia regulację prawną dotyczącą instytucji legalizacji samowoli budowlanej w Polsce w ujęciu historycznym oraz jej ewaluację. Zaprezentowano złożoność zagadnienia oraz trudność właściwego uregulowania prawnego tej materii. Od 19 września 2020 roku w Polsce obowiązują znowelizowane przepisy w zakresie procedury legalizacji samowoli budowlanych. Po zmianie prawa to w dalszym ciągu do organów nadzoru budowlanego należy ostateczna decyzja co do możliwości legalizacji samowolnej budowy. Jednakże odmiennie niż w poprzednim stanie prawnym wszczęcie procedury legalizacyjnej jest możliwe jedynie na wniosek inwestora. Ponadto ustawodawca wprowadził możliwość legalizacji samowoli budowlanych zrealizowanych ponad 20 lat temu w uproszczonym postępowaniu legalizacyjnym. W końcowej części opracowania przedstawiono wszystkie procedury legalizacji samowoli obowiązujące od 19 września 2020 roku oraz zawarto ogólne wnioski w zakresie opisywanej instytucji.

Słowa kluczowe: postępowanie administracyjne, prawo budowlane, samowola budowlana, legalizacja samowoli budowlanej 


\section{Wprowadzenie}

Fundamentem zachowania ładu w budownictwie, czyli jednej z istotniejszych gałęzi gospodarki jest ukształtowanie odpowiednich przepisów prawnych regulujących cały proces budowlany. Proces ten bowiem - poza oparciem się na wiedzy technicznej - jest unormowany prawnie [Małysa, 2002: 24]. W szerokim znaczeniu obejmuje on ustalenie miejsca budowy, projektowanie, wykonanie robót budowlanych, rozpoczęcie użytkowania, utrzymanie oraz rozbiórkę obiektu budowlanego. W wąskim znaczeniu natomiast pojęciem „,proces budowlany” posługuje się ustawodawca, kreując przepisy prawa budowlanego [Malanowski, Polarczyk, 2009: 145]. Ich tworzenie wynika z konieczności zintegrowania właściwych stosunków społecznych i gospodarczych [Jędrzejewski, 1994: 7]. Należy przy tym zauważyć, że dominujący zakres uregulowań w tym przedmiocie odnosi się do stosowania ogólnych zasad i reguł prawa administracyjnego [Małysa, 2002: 23].

W Polsce proces inwestycyjno-budowlany od zamierzenia budowlanego do oddania obiektu do użytkowania i jego rozbiórki jest normowany przez już wielokrotnie nowelizowaną ustawę z dnia 7 lipca 1994 roku - Prawo budowlane (t.j. Dz.U. 2020, poz. 1333 ze zm., dalej: Prawo budowlane, ustawa z 1994 roku), a także przez wiele aktów wykonawczych. Przepisami tymi organy administracji publicznej są uprawnione do władczej ingerencji w prawa jednostki w tym zakresie [Cherka, Grecki, 2013: 14]. Ustawa reguluje stosunki i zależności pomiędzy poszczególnymi uczestnikami procesu budowlanego, w tym określa wymogi, jakie inwestor zobowiązany jest spełnić $\mathrm{w}$ przypadku podjęcia zamierzenia budowlanego. $\mathrm{W}$ przepisach art. 28-30 Prawa budowlanego skatalogowano roboty budowlane, które: a) można rozpocząć jedynie na podstawie decyzji o pozwoleniu na budowę, b) wymagają dokonania zgłoszenia, c) nie wymagają decyzji o pozwoleniu na budowę ani dokonania zgłoszenia organowi administracji architektoniczno-budowlanej. W literaturze podkreśla się, że do procesu budowlanego nie zalicza się inwestycji realizowanych w ramach samowoli budowlanej. Rozpoczęcie takiego procesu następuje dopiero w momencie podjęcia pierwszej czynności w postępowaniu legalizacyjnym [Błażewski, 2016: 48, 50]. Jedyną bowiem drogą, by doprowadzić samowole budowlane do zgodności z prawem, jest ich legalizacja w procedurze, którą ustanawiają przepisy Prawa budowlanego.

Przepisy prawa nie zawierają definicji legalnej terminu ,samowola budowlana”. Należy jednak przyjąć, że samowolą budowlaną jest działanie inwestora zgodnie $\mathrm{z}$ własną wolą $\mathrm{w}$ sprawach budowlanych, $\mathrm{z}$ naruszeniem obowiązujących uregulowań prawnych. Powstała samowola może być powodowana w wielu przypadkach nieznajomością przepisów, a w innych - świadomą rezygnacją z drogi administracyjnej [Cherka, Grecki, 2013: 19]. Zjawisko samowoli jest znane ustawodawcy od początku prawodawstwa w dziedzinie procesu inwestycyjno-budowlanego, a prawna regulacja instytucji legalizacji samowoli budowlanej - ze względu na różne stany faktyczne $\mathrm{w}$ indywidualnych sprawach - jest złożoną kwestią [Cherka, Grecki, 2013: 36]. Dlatego też dotychczas ustawodawca w różnoraki sposób 
kreował procedury legalizacyjne [Niewiadomski, 2020: 495]. Wpływ na zmiany w zakresie regulacji procesu budowlanego miało wiele czynników, w tym transformacja ustrojowa, postęp naukowo-techniczny [Cherka, Grecki, 2013: 65], a także doktryna i orzecznictwo sądów administracyjnych.

Samowolę budowlaną zasadniczo traktuje się jako zjawisko negatywne, które wymaga działań represyjnych, czyli karzących - w sytuacji dokonania samowoli budowlanej - oraz działań restytucyjnych, czyli mających na celu przywrócenie do stanu zgodnego z prawem. Do podejmowania działań w tym zakresie upoważniono organy nadzoru budowlanego (zob. wyrok NSA z dnia 9 czerwca 2017 roku, II OSK 2600/15, wyrok WSA w Gorzowie Wielkopolskim z dnia 6 grudnia 2007 roku, II SA/Go 647/07). Efektywność działań podejmowanych przez organy nadzoru budowlanego $\mathrm{w}$ zakresie samodzielnego wyszukiwania samowolnie powstałych obiektów wydaje się przy tym niska. W większości wypadków bowiem organy nadzoru wszczynają postępowanie $\mathrm{z}$ urzędu na podstawie informacji przekazanych $w$ tym zakresie bezpośrednio od obywateli w ramach skarg na naruszenie praworządności. Z kolei ze względu na restrykcyjność przepisów legalizacyjnych, w tym wymóg uiszczenia opłaty legalizacyjnej, częstokroć inwestorzy dobrowolnie nie ujawniają wykonanych samowoli. Wymienione czynniki skutkują pozostawieniem obiektów budowlanych lub ich części w nieuregulowanym stanie prawnym przez wiele lat.

Niniejsze opracowanie w zakresie legalizacji samowoli budowlanych w Polsce powstało $\mathrm{w}$ związku ze zmianami wprowadzonymi ustawą $\mathrm{z}$ dnia 13 lutego 2020 roku o zmianie ustawy - Prawo budowlane oraz niektórych innych ustaw (Dz.U. 2020, poz. 471, dalej: nowelizacja obowiązująca od 19 września 2020 roku). Ustawą tą znowelizowano wiele istotnych instytucji Prawa budowlanego, a także znacznie zreformowano procedurę legalizacji samowoli budowlanych. Zgodnie z uzasadnieniem do projektu tej ustawy podstawowym motywem zmian była konieczność uproszczenia i przyspieszenia procesu inwestycyjno-budowlanego oraz zapewnienia większej stabilności podejmowanych w nim rozstrzygnięć (zob. uzasadnienie do rządowego projektu ustawy o zmianie ustawy Prawo budowlane oraz niektórych innych ustaw z dnia 23 grudnia 2019 roku, druk sejmowy nr 121, Sejm IX kadencji, dalej: druk sejmowy nr 121 - uzasadnienie).

$\mathrm{W}$ artykule posłużono się metodą formalno-dogmatyczną, polegającą na przeprowadzeniu wykładni wprowadzonych nowelizacją przepisów Prawa budowlanego - w świetle dotychczasowych przepisów, orzecznictwa Naczelnego Sądu Administracyjnego oraz wojewódzkich sądów administracyjnych - poświęconych omawianej instytucji, uzupełnionej o stosowną literaturę przedmiotu. Przedstawione zostaną procedury legalizacji samowoli budowlanych, umieszczone obecnie w odrębnym rozdziale 5a Prawa budowlanego pod tytułem Postępowanie w sprawie rozpoczęcia i prowadzenia robót budowlanych z naruszeniem ustawy, oraz motywy ich podjęcia zawarte w uzasadnieniu do projektu nowelizacji. Artykuł przedstawia stan prawny w zakresie legalizacji samowoli budowlanych $\mathrm{z}$ dwóch okresów - ujętych w odrębnych częściach opracowania - których punkt graniczny wyznacza nowelizacja obowiązująca od 19 września 2020 roku. 


\section{Zarys historyczny oraz przepisy Prawa budowlanego z 1994 roku w zakresie samowoli budowlanych w brzmieniu obowiązującym do 18 września 2020 roku}

Zgodnie z przepisami zawartymi w rozporządzeniu Prezydenta Rzeczypospolitej Polskiej z dnia 16 lutego 1928 roku o prawie budowlanym i zabudowaniu osiedli (Dz.U. 1928, nr 23, poz. 202) legalizacja samowoli była możliwa, a nakaz rozbiórki był orzekany ostatecznie i jedynie w sytuacjach, gdy wykluczone było doprowadzenie samowoli do stanu zgodnego z prawem [Cherka, Grecki, 2013: 68]. W myśl przepisów ustawy z dnia 31 stycznia 1961 roku - Prawo budowlane (Dz.U. 1961, nr 7, poz. 46) wręcz obowiązkiem, a nie uprawnieniem inwestora była legalizacja samowoli budowlanej. W tej regulacji wprowadzono również możliwość odroczenia wykonania rozbiórki i czasowego użytkowania obiektu ze względów społecznych i gospodarczych, w przypadkach gdy celowe okazało się wykorzystanie obiektu budowlanego. W dalszej kolejności stosownie do przepisów ustawy z dnia 24 października 1974 roku - Prawo budowlane (Dz.U. 1974, nr 38, poz. 229, dalej: Prawo budowlane z 1974 roku) organy administracji wpierw przeprowadzały postępowanie sprawdzające pod kątem umożliwienia usunięcia nieprawidłowości. Zasadniczo w tym okresie nakazy rozbiórki były rzadkością [Dziwiński, Ziemski, 2006: 213]. Prawo budowlane z 1974 roku zostało uchylone wraz z uchwaleniem obecnie obowiązującej ustawy z 1994 roku, jednakże zgodnie z przepisami przejściowymi (art. 103 ust. 2 Prawa budowlanego) ma ona $\mathrm{w}$ dalszym ciągu zastosowanie do inwestycji wykonanych w całości przed dniem 1 stycznia 1995 roku bez pozwolenia na budowę (zob. wyrok WSA w Białymstoku z dnia 12 grudnia 2019 roku, II SA/Bk 480/18, wyrok WSA w Opolu z dnia 30 stycznia 2020 roku, SA/Op 307/19) lub w stosunku do których przed tym dniem zostało wszczęte postępowanie administracyjne.

Jak już wyżej wskazano, obecnie obowiązujące Prawo budowlane zostało uchwalone 7 lipca 1994 roku i weszło w życie 1 stycznia 1995 roku. W przepisach regulujących zakres samowoli budowlanych początkowo przyjęto bezwarunkowy nakaz rozbiórki samowoli budowlanej zrealizowanej bez wymaganego pozwolenia czy też zgłoszenia. Jednakże tak restrykcyjna regulacja ze względu na zbyt pokaźną represyjność była krytykowana przez doktrynę i judykaturę [Dziwiński, Ziemski, 2006: 213-214]. Wobec tego od ustanowienia w 1994 roku przepisu bezwarunkowej rozbiórki w dalszej kolejności ustawodawca wprowadzał przepisy łagodzące skutki dokonania samowoli budowlanej, umożliwiając jej legalizację. W 2003 roku ustawą z dnia 27 marca 2003 roku o zmianie ustawy - Prawo budowlane oraz o zmianie niektórych ustaw (Dz.U. 2003, nr 80, poz. 718) ustanowiono możliwość odstąpienia od obowiązku orzekania nakazu rozbiórki obiektu budowlanego. A zatem nastąpił powrót - co do zasady - do rozwiązań powszechnie funkcjonujących w krajach Unii Europejskiej [Niewiadomski, 2020: 495], a także do rozwiązań przewidzianych we wcześniejszych uregulowaniach. Przyjęto, że nakaz rozbiórki obiektu może być orzeczony dopiero wówczas, gdy okaże się, że nie ma prawnych możliwości jego legalizacji. Należy przy tym podkreślić, 
że zgodnie z przepisami ustawy z 1994 roku legalizacja samowoli budowlanej jest uprawnieniem, a nie obowiązkiem inwestora (zob. wyrok NSA z dnia 24 sierpnia 2016 roku, II OSK 2947/14).

Wobec tego, że przepisy nowelizujące nie obejmują prowadzonych postępowań dotychczas niezakończonych, a postępowania te $\mathrm{w}$ dalszym ciągu będą procedowane zgodnie z procedurą ustawy z 1994 roku obowiązującą do 18 września 2020 roku, w niniejszym artykule przedstawiono szerzej również te uregulowania. Do 18 września 2020 roku przepisy regulujące postępowanie legalizacyjne w zakresie samowoli budowlanych umiejscowione w art. 48 oraz art. 49 i art. $49 \mathrm{~b}$ Prawa budowlanego wyznaczały dwie procedury legalizacji samowoli budowlanych.

W art. 48 i art. 49 (w brzmieniu obowiązującym do 18 września 2020 roku) zawarta była procedura legalizacji obiektu budowlanego lub jego części, będącego w budowie albo wybudowanego bez wymaganego pozwolenia na budowę, albo bez wymaganego zgłoszenia dotyczącego budowy, o której mowa w art. 29 ust. 1 pkt 1a, 2b i 19a, a także pomimo wniesienia sprzeciwu do tego zgłoszenia. Organ nadzoru budowlanego we wszczętym postępowaniu winien był wpierw ocenić zgodność obiektu z przepisami o planowaniu i zagospodarowaniu przestrzennym, a także określić, czy obiekt nie narusza przepisów - w tym techniczno-budowlanych - w zakresie uniemożliwiającym jego doprowadzenie do stanu zgodnego z prawem [Dziwiński, Ziemski, 2006: 213]. W sytuacji stwierdzenia niemożliwości legalizacji organ zobowiązany był do obligatoryjnego nałożenia nakazu rozbiórki samowoli (zob. wyrok NSA z dnia 9 sierpnia 2013 roku, II OSK 756/12). W przypadku stwierdzenia możliwości legalizacji samowoli budowlanej organ postanowieniem wstrzymywał prowadzenie robót budowlanych oraz nakładał na inwestora obowiązek wykonania niezbędnych zabezpieczeń budowy oraz przedstawienia dokumentacji (zob. art. 48 ust. 3). Przedłożenie w wyznaczonym terminie żądanych dokumentów uznawano za potwierdzenie woli i zamierzenia inwestora, jakim była legalizacja obiektu. W przypadkach gdy budowa nie została zakończona, przedłożenie dokumentacji traktowano jako wniosek o zatwierdzenie projektu budowlanego i pozwolenie na wznowienie robót budowlanych (art. 48 ust. 5 Prawa budowlanego) (zob. wyrok WSA w Poznaniu z dnia 6 lutego 2020 roku, IV SA/Po 965/19). Stwierdzenie naruszeń w zakresie przedłożonej dokumentacji skutkowało postanowieniem o obowiązku usunięcia wskazanych nieprawidłowości w określonym terminie (art. 49 ust. 3). Pozytywna ocena przedłożonej dokumentacji (zob. wyrok NSA z dnia 12 września 2019 roku, II OSK 2534/17) umożliwiała wydanie postanowienia o ustaleniu wysokości opłaty legalizacyjnej (art. 49 ust. 1 pkt 3) z 7-dniowym terminem na jej uiszczenie. Od postanowienia o nałożeniu opłaty przysługiwało zażalenie, a ponadto wniosek do wojewody o umorzenie opłaty legalizacyjnej lub rozłożenie jej na raty. W wyniku spełnienia wymagań w zakresie dokumentacji i uiszczenia opłaty legalizacyjnej organ nadzoru budowlanego wydawał decyzję o zatwierdzeniu projektu budowlanego i pozwoleniu na wznowienie robót albo decyzję zatwierdzającą projekt budowlany, jeżeli budowa została zakończona (art. 49 ust. 4). Niespełnienie wymogów w zakresie dokumentacji oraz nieuiszczenie opłaty legalizacyjnej zobowiązywało organ nadzoru do wydania decyzji nakazującej rozbiórkę (zob. wyrok NSA 
z dnia 7 listopada 2019 roku, II OSK 3163/17, wyrok WSA w Łodzi z dnia 18 stycznia 2019 roku, II SA/Łd 686/18, wyrok WSA w Poznaniu z dnia 28 grudnia $2018 \mathrm{roku}$, II SA/Po 622/18).

$\mathrm{W}$ art. 49b określono konsekwencje budowy obiektu budowlanego lub jego części bez wymaganego zgłoszenia bądź budowy pomimo wniesienia sprzeciwu przez organ administracji architektoniczno-budowlanej. Co do zasady procedura legalizacyjna była tożsama $\mathrm{z}$ uregulowaniami zawartymi w art. 48. Postępowania rozróżniał w głównej mierze zakres wymaganych dokumentów i wysokość opłat legalizacyjnych (zob. wyrok WSA w Warszawie z dnia 20 kwietnia 2017 roku, VII SA/Wa 1240/16). W przypadku niezakończonych robót postępowanie legalizacyjne prowadzone na podstawie art. 49b kończyło wydanie postanowienia o zezwoleniu na dokończenie budowy, a w przypadku robót zakończonych przed wszczęciem takiej procedury, legalizował je sam fakt wniesienia opłaty legalizacyjnej [Niewiadomski, 2020: 534].

Powyższe tryby (art. 48, art. 49, art 49b) wzajemnie się wykluczały, a prawidłowe zastosowanie jednego z nich zależne było przede wszystkim od stanu faktycznego i prawnego sprawy [Cherka, Grecki, 2013: 128]. Organ nadzoru budowlanego każdorazowo zobowiązany był do dokonania prawidłowej kwalifikacji wykonanych robót budowlanych, czyli stwierdzenia, czy na budowę danego obiektu wymagane było uzyskanie pozwolenia na budowę, czy też dokonanie zgłoszenia (zob. wyrok WSA w Gdańsku z dnia 6 listopada 2019 roku, II SA/Gd 286/19). W praktyce zdarzały się przypadki, w których organy stosowały nieprawidłowe procedury (zob. wyrok WSA w Warszawie z dnia 30 maja 2018 roku, VII SA/Wa 1931/17).

\section{Obecnie obowiązująca procedura legalizacyjna (od 19 września 2020 roku)}

Nowelizacja w sposób znaczący zmieniła procedurę wszczynania i prowadzenia postępowań administracyjnych przez organy nadzoru budowlanego w sprawach samowoli budowlanych. Wprowadzenie gruntownych zmian potwierdza także uzasadnienie do projektu ustawy nowelizującej, zgodnie z którym procedura prowadzenia przez organy nadzoru budowlanego postępowania w sprawie samowoli budowlanej została na nowo ukształtowana i uregulowana. Zamierzeniem ustawodawcy było uproszczenie, doprecyzowanie wszelkich zawiłości i wyeliminowanie dotychczasowych niejasności w powyższym zakresie (zob. druk sejmowy nr 121 - uzasadnienie). Obecnie każdy kolejny przepis chronologicznie przedstawia etapy postępowania legalizacyjnego.

Procedurę w zakresie samowoli budowlanych rozpoczyna ustalenie przez organ nadzoru budowlanego przedmiotu postępowania. W myśl art. 48 ust. 1 pkt 1 i 2 samowolą budowlaną jest obiekt budowlany lub jego część będący w budowie albo już wybudowany bez wymaganej decyzji o pozwoleniu na budowę albo bez wymaganego zgłoszenia (lub pomimo wniesienia sprzeciwu do tego zgłoszenia). 
W przypadku stwierdzenia powyższego organ wydaje postanowienie o wstrzymaniu budowy. Postanowienie to wydaje się niezależenie od tego, czy budowa została już zakończona, czy też jest jeszcze prowadzona (art. 48 ust. 5). Dodatkowo, gdy organ stwierdzi, że w wyniku budowy wystąpił stan zagrożenia życia lub zdrowia ludzi, w postanowieniu o wstrzymaniu budowy nakaże bezzwłoczne zabezpieczenie obiektu budowlanego lub terenu, na którym prowadzona jest budowa, oraz usunięcie stanu zagrożenia (art. 48 ust. 2 pkt 1 i 2). Postanowienie wstrzymujące jako pierwsza informacja co do możliwości wszczęcia procedury legalizacyjnej jest istotnym aktem dla całego dalszego procedowania w sprawie samowoli budowlanej. Należy zauważyć, że na tym etapie rola organu nadzoru budowlanego sprowadza się do jednoznacznego stwierdzenia zaistnienia samowoli budowlanej oraz - w razie stanu zagrożenia - do nakazania wykonania doraźnych środków zabezpieczających i usunięcia zagrożenia. W tym postanowieniu inwestor dokonujący samowoli, a także właściciel lub zarządca obiektu budowlanego zostaną poinformowani o możliwości złożenia wniosku o legalizację obiektu budowlanego lub jego części oraz o konieczności wniesienia opłaty legalizacyjnej w celu uzyskania decyzji o legalizacji, a także o zasadach jej obliczania (art. 48 ust. 3). Rozstrzygnięcie to będzie mogło zostać skontrolowane w postępowaniu zażaleniowym przez organ drugiej instancji. W terminie 30 dni od dnia otrzymania postanowienia o wstrzymaniu budowy inwestor, właściciel lub zarządca obiektu budowlanego może złożyć wniosek o legalizację (art. 48a ust. 1). Okres ten jest pozostawiony nie tylko inwestorowi, ale także właścicielowi lub zarządcy obiektu. Powyższe podmioty mają w tym czasie możliwość zdecydowania, czy chcą podjąć się legalizacji samowolnie zrealizowanej inwestycji, czy też nie. Termin 30-dniowy do wniesienia wniosku o legalizację jest liczony od chwili uzyskania ostateczności postanowienia o wstrzymaniu budowy w przypadku wniesienia zażalenia (art. 48a ust. 3), czyli od dnia wydania przez organ odwoławczy postanowienia utrzymującego postanowienie o wstrzymaniu w mocy. Należy w tym miejscu zauważyć, że powyższymi uregulowaniami ustawodawca przerzucił odpowiedzialność za podjęcie decyzji o wszczęciu postępowania legalizacyjnego $\mathrm{z}$ organu nadzoru na inwestora, właściciela lub zarządcę obiektu budowlanego. Inicjatywa w zakresie wszczęcia postępowania legalizacyjnego jest uprawnieniem wymienionych podmiotów i jest uzależniona od ich wniosku.

Właściwą procedurę legalizacyjną, czyli postępowanie legalizacyjne rozpoczyna dopiero wydanie kolejnego postanowienia, wskutek złożenia wniosku o legalizację (art. 48b ust. 1). Postanowieniem tym organ nadzoru budowlanego nakłada obowiązek przedłożenia dokumentów legalizacyjnych w terminie nie krótszym niż 60 dni od dnia doręczenia tego postanowienia. W stosunku do tego postanowienia nie przewidziano możliwości złożenia zażalenia. Ustawodawca rozgraniczył również, jaką dokumentację należy przedłożyć w przypadku budowy wymagającej decyzji o pozwoleniu na budowę lub w przypadku budowy, o której mowa w art. 29 ust. 1 pkt 1-3 (art. 48 b ust. 2), a jaką dokumentację w przypadku budowy innej niż budowa, o której mowa w ust. 2 (art. 48 b ust. 3).

Jedną z podstawowych zmian w procedurze legalizacji jest to, że dotychczas to organ nadzoru w początkowej fazie postępowania legalizacyjnego zobowiązany 
był do dokonania samodzielnych ustaleń w zakresie zgodności samowoli z ustaleniami planistycznymi oraz z obowiązującymi przepisami, w tym techniczno-budowlanymi [Niewiadomski, 2020: 504]. Od tego bowiem uzależniony był dalszy tok postępowania legalizacyjnego. Obecnie natomiast to inwestor w wyniku wyrażenia woli legalizacji, po otrzymaniu postanowienia nakazującego przedłożenie dokumentacji winien dokonać tych ustaleń we własnym zakresie i uzyskać żądaną dokumentację. Zmiana ta odciąża zatem organy nadzoru budowlanego w zakresie dokonywania analizy przepisów prawa miejscowego i wyłącznie je zobowiązuje do sprawdzenia kompletności przedłożonych dokumentów legal zacyjnych, w tym kompletności projektu budowlanego oraz zgodności projektu zagospodarowania działki lub terenu z przepisami Prawa budowlanego oraz zgodności z przepisami techniczno-budowlanymi (art. 49 ust. 1). W przypadku gdy budowa została zakończona, organ nadzoru budowlanego sprawdza zgodność inwestycji z przepisami obowiązującymi w chwili zakończenia budowy. Niewątpliwie takie uregulowanie spowoduje również, że organy te nie będą mogły zostać obciążane odpowiedzialnością za wydatkowane przez inwestorów środki finansowe na sporządzenie dokumentacji legalizacyjnej w sytuacji, gdyby jednak okazało się, że legalizacja nie jest możliwa. Stwierdzenie nieprawidłowości w zakresie kompletności i zgodności z przepisami przedłożonej dokumentacji uprawnia organ do nałożenia postanowieniem obowiązku usunięcia tych nieprawidłowości w wyznaczonym terminie (art. 49 ust. 1a). Na postanowienie o uzupełnienie dokumentacji - odmiennie niż w stosunku do podstawowego postanowienia nakazującego przedłożenie dokumentacji - stronom przysługuje zażalenie. Jest to słuszne podejście. Skoro bowiem strona wniosła o legalizację, to z góry oczywiste jest, że organ wyda postanowienie nakazujące przedłożenie dokumentacji. Zażalenie na to rozstrzygnięcie zbędnie przedłużałoby procedurę legalizacyjną. Natomiast w przypadku przedłożenia dokumentacji, która zgodnie z odczuciem strony jest kompletna, zażalenie na postanowienie o uzupełnieniu wydaje się właściwe i celowościowe. Organ drugiej instancji w tym wypadku jest zobowiązany do oceny zasadności wydania postanowienia o uzupełnieniu dokumentacji, a tym samym oceny kompletności i zgodności przedłożonej dokumentacji.

Okoliczność stwierdzenia zgodności przedłożonej dokumentacji zobowiązuje organ nadzoru do wydania postanowienia o ustaleniu wysokości opłaty legalizacyjnej, na które przysługuje zażalenie (art. 49 ust. 2a i 2b). Wysokość i sposób naliczania opłat legalizacyjnych nie zostały zmienione w nowelizacji obowiązującej od 19 września 2020 roku. Dopuszczalne jest złożenie wniosku o odroczenie terminu płatności, rozłożenie na raty lub umorzenie opłaty legalizacyjnej zgodnie z art. 67a $\S 1$ ustawy z dnia 29 sierpnia 1997 roku - Ordynacja podatkowa (t.j. Dz.U. 2020, poz. 1325 ze zm.). Taki wniosek skutkuje zawieszeniem postępowania prowadzonego na podstawie art. 48 do dnia jego rozstrzygnięcia, a w przypadku rozłożenia opłaty legalizacyjnej na raty lub odroczenia płatności do dnia upływu terminu wniesienia całej opłaty. Ostatnim etapem postępowania legalizacyjnego, po uiszczeniu opłaty jest wydanie przez organ nadzoru budowlanego decyzji o legalizacji oraz zatwierdzającej projekt budowlany albo projekt zagospodarowania działki lub terenu, oraz zezwalającej na wznowienie budowy, 
jeżeli budowa nie została zakończona (art. 49 ust. 4 Prawa budowlanego). Od tej decyzji stronie przysługuje odwołanie. W przypadku uchylenia decyzji opłata legalizacyjna podlega zwrotowi w terminie 30 dni od dnia stwierdzenia wykonania rozbiórki (art. 49a ust. 1).

W nowych uregulowaniach wprowadzono i skatalogowano $\mathrm{w}$ jednym artykule (art. 49e) przesłanki zobowiązujące organ nadzoru budowlanego do wydania decyzji o rozbiórce obiektu budowlanego lub jego części. Są to przypadki: niezłożenia wniosku o legalizację w wymaganym terminie; wycofania wniosku o legalizację; nieprzedłożenia w wyznaczonym terminie dokumentów legalizacyjnych; niewykonania, w wyznaczonym terminie, postanowienia o usunięciu nieprawidłowości w dokumentach legalizacyjnych; nieuiszczenia opłaty legalizacyjnej w wyznaczonym terminie; kontynuowania budowy pomimo postanowienia o wstrzymaniu budowy. Uregulowanie to winno usprawnić wydawanie przez organy decyzji rozbiórkowych, ponieważ we wskazanych niezaprzeczalnych sytuacjach organ poza stwierdzeniem zaistnienia przesłanek do wydania nakazu rozbiórki samowoli nie musi już prowadzić dodatkowego postępowania wyjaśniającego.

\section{Uproszczona procedura legalizacyjna}

Nowelizacja obowiązująca od 19 września 2020 roku wprowadziła do Prawa budowlanego również całkowicie nową procedurę legalizacyjną - tak zwane uproszczone postępowanie legalizacyjne (art. 49f-i). Jest to precedensowo wprowadzony w Polsce tok postępowania umożliwiający legalizację samowoli budowlanych - nawet dosłownie niezgodnych z przepisami prawa (miejscowymi planami zagospodarowania przestrzennego) - bez opłaty legalizacyjnej. Uproszczone postępowanie legalizacyjne może być wszczęte przez organ nadzoru budowlanego i przeprowadzone w przypadku stwierdzenia budowy obiektu budowlanego lub jego części bez wymaganej decyzji o pozwoleniu na budowę albo bez wymaganego zgłoszenia albo pomimo wniesienia sprzeciwu do tego zgłoszenia pod warunkiem, że od realizacji inwestycji minęło 20 lat, a organ nadzoru w tym okresie nie wszczynał postępowania legalizacyjnego. Istotnym argumentem umożliwiającym zastosowanie postępowania uproszczonego ma być tym samym brak skarg wnoszonych w tym okresie do organów nadzoru budowlanego w sprawie danej inwestycji. Dodatkowo z treści uchwalonych przepisów wynika, że bez znaczenia w uproszczonej procedurze legalizacyjnej jest również zgodność realizacji tych obiektów z przepisami technicznymi, z wyjątkiem gdy niezgodność ta powoduje zagrożenie dla zdrowia i życia ludzi oraz ma wpływ na możliwość bezpiecznego użytkowania obiektu. Ponadto dokumentacja, którą należy przedłożyć, jest znacznie uproszczona w stosunku do tej, którą należy przedłożyć w zwykłej procedurze legalizacyjnej.

Zgodnie z nowymi uregulowaniami, gdy organ w wyniku wszczęcia z urzędu uproszonego postępowania legalizacyjnego stwierdzi stan zagrożenia życia lub zdrowia ludzi, to bezzwłocznie nakaże - w drodze postanowienia, na które 
przysługuje zażalenie - zabezpieczenie obiektu budowlanego lub jego części oraz usunięcie stanu zagrożenia (art. 49f ust. 3). Postanowieniem organ nakazuje w terminie nie krótszym niż 60 dni od dnia jego doręczenia - przedłożenie dokumentów legalizacyjnych, czyli: oświadczenia o prawie do dysponowania nieruchomością na cele budowlane, geodezyjnej inwentaryzacji powykonawczej obiektu budowlanego oraz ekspertyzy technicznej, sporządzonej przez osobę posiadającą odpowiednie uprawnienia budowlane. $Z$ ekspertyzy powinno wynikać, czy stan techniczny obiektu budowlanego nie stwarza zagrożenia dla życia lub zdrowia ludzi, oraz czy pozwala na bezpieczne użytkowanie obiektu budowlanego zgodne $\mathrm{z}$ dotychczasowym lub zamierzonym sposobem użytkowania. Przedłożenie żądanej dokumentacji zobowiązuje organ do przeprowadzenia analizy pod kątem jej kompletności. Stwierdzenie braków w dokumentacji legalizacyjnej skutkuje postanowieniem o obowiązku usunięcia niekompletności w wyznaczonym terminie (art. 49h ust. 2). Pozytywna ocena przedłożonej dokumentacji obliguje organ nadzoru do wydania decyzji o legalizacji, która jest zarazem decyzją pozwalającą na użytkowanie obiektu. Taka decyzja jest podstawą do użytkowania samowolnie wykonanego obiektu (art. 49i ust. 1). Z kolei nakaz rozbiórki jest orzekany w przypadku: nieprzedłożenia dokumentów legalizacyjnych w wyznaczonym terminie, nieuzupełnienia dokumentacji nałożonej postanowieniem, a także w sytuacji, gdy z ekspertyzy technicznej wynikać będzie, że stan techniczny obiektu budowlanego stwarza zagrożenie dla życia lub zdrowia ludzi, lub nie pozwala na bezpieczne użytkowanie obiektu budowlanego zgodne $\mathrm{z}$ dotychczasowym lub zamierzonym sposobem użytkowania (art. 49i ust. 2). Z powyższego wynika, że uproszone postępowanie legalizacyjne cechuje bezwarunkowość możliwych rozstrzygnięć, bowiem w sytuacji stwierdzenia nieprawidłowości w zakresie stanu technicznego obiektu ustawodawca nie przewiduje ewentualnej możliwości ich usunięcia. Stan techniczny uznano bowiem za jedną z przesłanek wydania decyzji nakazującej rozbiórkę obiektu. Fakt ten zapewne wpłynie na odpowiednią kolejność czynności podejmowanych przez właścicieli takich obiektów.

$Z$ uwagi na to, że co do samowoli budowlanych powstałych jeszcze przed wejściem w życie obowiązującego Prawa budowlanego (przed 1 stycznia 1995 roku) stosuje się przepisy Prawa budowlanego z 1974 roku, właściciel lub zarządca obiektu będzie mógł samodzielnie zadecydować, czy zamiast zastosowania tych przepisów chciałby, aby organ zastosował procedurę uproszczonego postępowania legalizacyjnego. Wydaje się, że procedura uproszona jest korzystniejsza, bowiem organ w przypadku jej zastosowania nie bada przepisów o planowaniu przestrzennym, co dotychczas $\mathrm{w}$ wielu przypadkach uniemożliwiało legalizację obiektów lub ich części.

W uzasadnieniu do projektu ustawy wskazano na dotychczasowy brak możliwości przedawnienia samowoli budowlanych w polskim systemie prawnym (zob. druk sejmowy nr 121 - uzasadnienie). Organy nadzoru budowlanego są bowiem zobligowane do podejmowania działań $\mathrm{w}$ sytuacji powzięcia informacji o samowoli budowlanej niezależnie od daty powstania obiektu. Ustawodawca świadom istnienia $\mathrm{w}$ dalszym ciągu samowoli budowlanych zrealizowanych przed laty, a dotychczas niedoprowadzonych do stanu zgodnego z prawem, podkreślił 
zasadność zalegalizowania użytkowanych przez ponad 20 lat, a tym samym trwale wpisanych przestrzeń, obiektów budowlanych mimo ich samowolnego wykonania. Przyjęto, że istnienie samowolnie wykonanych obiektów przez tak długi okres świadczy w pewien sposób o ich akceptowaniu przez społeczność lokalną. Legalizacja powstałych samowolnie przed laty obiektów ma umożliwić - przez ich wprowadzenie do obrotu gospodarczego - realny nadzór nad ich stanem technicznym dokonywany przez organy administracji, a także uaktualnić ewidencje gruntów i budynków oraz zwiększyć wpływy do gmin z tytułu podatku od nieruchomości [Gierach, 2020: 7].

Wprowadzoną regulację należy ocenić dodatnio - tak znaczne uproszenia mogą bowiem rzeczywiście zachęcić właścicieli lub zarządców obiektów do dobrowolnego i samodzielnego wystąpienia do organów nadzoru o przeprowadzenie uproszczonego postępowania legalizacyjnego. Ponadto - w porównaniu z opisaną zwykłą procedurą legalizacyjną (uprzednio lub też obecnie obowiązującą) - procedura uproszczona jest znacznie mniej dotkliwa dla stron legalizujących samowolę.

\section{Zakończenie i wnioski}

Prawodawstwo w zakresie procesu inwestycyjno-budowlanego już kilkukrotnie podejmowało próby regulowania instytucji legalizacji samowoli budowlanej. Jak wykazano, problematyka prawidłowego przeprowadzenia postępowania legalizacyjnego jest wielopłaszczyznowa. Znowelizowane przepisy mają przyśpieszyć i ułatwić legalizację samowoli budowlanych, przez ich uporządkowanie, ujednolicenie i uproszczenie. Biorąc pod uwagę różnorodność inwestycji w zakresie zastosowanych technologii, poniesionych środków finansowych, a także niezwykłą niejednolitość stanów faktycznych i prawnych, należy stwierdzić, że za każdym razem sprawa w zakresie legalizacji samowoli budowlanej jest indywidualna. Tym samym organom nadzoru budowlanego trudno było - i pewnie będzie w dalszym ciągu wypracować wzorce, które pomogłyby usprawnić i przyśpieszyć prowadzone latami postępowania legalizacyjne.

Podsumowując, należy zauważyć, że od dnia 19 września 2020 roku postępowania legalizacyjne w Polsce prowadzone są na podstawie czterech procedur legalizacyjnych:

1) przepisów Prawa budowlanego z 1974 roku w stosunku do inwestycji wykonanych samowolnie w całości przed dniem 1 stycznia 1995 roku bez pozwolenia na budowę,

2) w myśl przepisów przejściowych - postępowania prowadzone dotychczas w zakresie samowoli budowlanych i niezakończone w dalszym ciągu będą procedowane zgodnie z ustawą z 1994 roku obowiązującą do dnia 18 września 2020 roku,

3) zgodnie ze znowelizowanymi przepisami art. 48 i 49a-d Prawa budowlanego (nowelizacja obowiązująca od dnia 19 września 2020 roku),

4) uproszczone postępowanie legalizacyjne. 
Zarówno dotychczasowe orzecznictwo sądów administracyjnych, jak i obecne stanowisko doktryny będą przede wszystkim pomocne w stosunku do niezakończonych dotychczas postępowań legalizacyjnych. $Z$ kolei nowo unormowana zwykła procedura legalizacji samowoli budowlanych - ze względu na daleko idące zmiany przepisów - budzi wiele wątpliwości i zastrzeżeń, co do których nie ma jeszcze ani orzecznictwa, ani wyraźnego stanowiska doktryny. Dlatego też tak ważne jest zapoznanie szerokiego kręgu odbiorców z jej postanowienia$\mathrm{mi}$, tak aby proces wprowadzania uchwalonych zmian Prawa budowlanego był jak najbardziej sprawny i skuteczny.

\section{Bibliografia}

\section{Akty prawne}

Rozporządzenie Prezydenta Rzeczypospolitej Polskiej z dnia 16 lutego 1928 roku o prawie budowlanym i zabudowaniu osiedli, Dz.U. 1928, nr 23, poz. 202.

Rządowy projekt ustawy o zmianie ustawy Prawo budowlane oraz niektórych innych ustaw z dnia 23 grudnia 2019 roku wraz z uzasadnieniem, druk nr 121 Sejmu RP IX kadencji.

Ustawa z dnia 31 stycznia 1961 roku - Prawo budowlane, Dz.U. 1961, nr 7, poz. 46.

Ustawa z dnia 24 października 1974 roku - Prawo budowlane, Dz.U. 1974, nr 38, poz. 229.

Ustawa z dnia 29 sierpnia 1997 roku - Ordynacja podatkowa, t.j. Dz.U. 2020, poz. 1325 ze zm.

Ustawa z dnia 7 lipca 1994 roku - Prawo budowlane, t.j. Dz.U. 2020, poz. 1333 ze zm.

Ustawa z dnia 27 marca 2003 roku o zmianie ustawy - Prawo budowlane oraz o zmianie niektórych ustaw, Dz.U. 2003, nr 80, poz. 718.

Ustawa z dnia 13 lutego 2020 roku o zmianie ustawy - Prawo budowlane oraz niektórych innych ustaw, Dz.U. 2020, poz. 471.

\section{Orzecznictwo}

Wyrok NSA z dnia 9 sierpnia 2013 roku, II OSK 756/12.

Wyrok NSA z dnia 24 sierpnia 2016 roku, II OSK 2947/14.

Wyrok NSA z dnia 9 czerwca 2017 roku, II OSK 2600/15.

Wyrok NSA z dnia 12 września 2019 roku, II OSK 2534/17.

Wyrok NSA z dnia 7 listopada 2019 roku, II OSK 3163/17.

Wyrok WSA w Gorzowie Wielkopolskim z dnia 6 grudnia 2007 roku, II SA/Go 647/07.

Wyrok WSA w Warszawie z dnia 20 kwietnia 2017 roku, VII SA/Wa 1240/16.

Wyrok WSA w Warszawie z dnia 30 maja 2018 roku, VII SA/Wa 1931/17.

Wyrok WSA w Poznaniu z dnia 28 grudnia 2018 roku, II SA/Po 622/18.

Wyrok WSA w Łodzi z dnia 18 stycznia 2019 roku, II SA/Łd 686/18.

Wyrok WSA w Gdańsku z dnia 6 listopada 2019 roku, II SA/Gd 286/19.

Wyrok WSA w Białymstoku z dnia 12 grudnia 2019 roku, II SA/Bk 480/18. 
Wyrok WSA w Opolu z dnia 30 stycznia 2020 roku, SA/Op 307/19.

Wyrok WSA w Poznaniu z dnia 6 lutego 2020 roku, IV SA/Po 965/19.

\section{Literatura}

Błażewski M. (2016), Zasada wolności budowlanej w procesie budowlanym, Studium administracyjnoprawne, E-Wydawnictwo. Prawnicza i Ekonomiczna Biblioteka Cyfrowa. Wydział Prawa, Administracji i Ekonomii Uniwersytetu Wrocławskiego, Wrocław.

Cherka. M., Grecki W. (2013), Samowola budowlana w polskim prawie budowlanym, Wolters Kluwer Polska, Warszawa.

Dziwiński R., Ziemski P. (2006), Prawo budowlane. Komentarz, Dom Wydawniczy ABC, Warszawa.

Gierach E. (2020), Ocena skutków prawnych rządowego projektu ustawy o zmianie ustawyPrawo budowlane oraz niektórych innych ustaw (druk sejmowy nr 121), Biuro Analiz Sejmowych Kancelarii Sejmu, Warszawa.

Jędrzejewski S. (1994), Nowe prawo budowlane, Oficyna Wydawnicza Branta, Bydgoszcz.

Malanowski J., Polarczyk D. (2009), Zasady ogólne Kodeksu postępowania administracyjnego w procesie inwestycyjnym [w:] M. Cherka, F. Elżanowski, K. Wąsowski (red.), Prawne aspekty procesu inwestycyjnego, Wolters Kluwer Polska, Warszawa.

Małysa K. (2002), Proces inwestycyjno-budowlany, Kantor Wydawniczy Zakamycze, Kraków. Niewiadomski Z. (red.) (2020), Prawo budowlane. Komentarz, C.H. Beck, Warszawa. 